\title{
Uji Aktivitas Anti-aging Mikroemulsi Minyak Nilam (Pogostemon cablin Benth.)
}

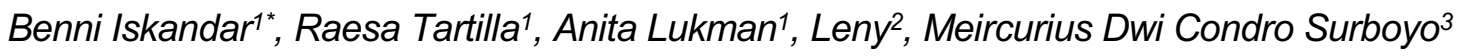

1 Departemen Farmasetika, Fakultas Farmasi, Sekolah Tinggi IImu Farmasi Riau, Pekanbaru, Riau, Indonesia

2 Fakultas Farmasi dan IImu Kesehatan, Institut Kesehatan Helvetia, Medan, Sumatera Utara, Indonesia

${ }^{3}$ Fakultas Kedokteran Gigi, Universitas Airlangga, Jawa Timur, Surabaya, Indonesia

*Email: benniiskandar@stifar-riau.ac.id

(Submit 4/11/2021, Revisi 28/11/2021, Diterima 17/12/2021, Terbit 12/2/2022)

\section{Abstrak}

Penuaan merupakan proses penurunan fungsi fisiologis dan terjadi pada semua organ tubuh manusia, termasuk kulit. Paparan sinar matahari langsung pada kulit mengakibatkan kelebihan radikal bebas dalam tubuh. Radikal bebas dalam tubuh dapat memicu terjadinya penuaan dini. Gejala yang jelas terlihat diantaranya munculnya keriput, kulit kering dan kasar serta timbulnya noda-noda gelap pada kulit. Salah satu upaya mengatasi penuaan adalah dengan antioksidan. Minyak nilam (Pogostemon cablin Benth.) telah terbukti memiliki efek antioksidan. Tujuan penelitian ini adalah menguji aktivitas anti-aging dari sediaan mikroemulsi minyak nilam. Penelitian ini dilakukan dengan membuat sediaan mikroemulsi minyak nilam pada konsentrasi $0 \%$ (F0), 5\% (F1), 10\% (F2), dan 15\% (F3). Sediaan kemudian diujikan pada kulit punggung tangan sukarelawan dengan menggunakan alat skin analyzer dengan parameter yang diukur meliputi kadar air, kehalusan, besar pori, banyak noda, dan keriput. Pengaplikasian sediaan mikroemulsi pada kulit punggung tangan sebanyak dua kali sehari selama 30 hari. Pengujian dilakukan setiap hari ke-10, ke-20, dan ke-30. Hasil uji aktivitas anti-aging menunjukkan bahwa sediaan mikroemulsi minyak nilam 5\% (F1) lebih cepat terjadi pemulihan dalam meningkatkan kadar air, kehalusan kulit, mengecilkan ukuran pori, mengurangi noda dan keriput.

Kata kunci: Anti-aging, mikroemulsi, minyak nilam, penuaan

\section{Pendahuluan}

Indonesia merupakan negara tropis yang penuh dengan limpahan sinar matahari sepanjang tahunnya. Matahari dapat memancarkan berbagai macam sinar, baik yang dapat dilihat maupun yang tidak dapat dilihat. Sinar matahari yang dapat dilihat adalah sinar yang dipancarkan dalam gelombang lebih dari $400 \mathrm{~nm}$, sedangkan sinar matahari dengan panjang gelombang $10 \mathrm{~nm}-400 \mathrm{~nm}$ yang disebut dengan sinar ultra violet (UV). Paparan sinar UV pada kulit dapat menimbulkan reaksi akut seperti terbakar nya kulit akibat sinar matahari (sunburn), imunosupresi, dan stres oksidatif; sedangkan efek paparan sinar UV yang kronis dapat mengakibatkan penuaan dini ${ }^{\text {. }}$ 
Kerut pada kulit merupakan salah satu dari tanda penuaan dini, di mana terjadi pengurangan jumlah kolagen serta elastin pada dermis yang mengakibatkan bagian epidermis mengalami penurunan tekstur. Faktor pemicunya adalah paparan sinar matahari, stress, dan senyawa radikal bebas ${ }^{2}$.

Kelebihan radikal bebas atau oxidative stress yang disebabkan oleh sinar UV dapat mengakibatkan kerusakan pada sel yang sehat serta menyebabkan penurunan kolagen, sehingga sel kulit mengalami penuaan. Pada saat sel kulit serta kolagen mengalami kerusakan, dampak terbesar yang akan terjadi adalah premature aging atau penuaan dini. Hal yang dapat dilakukan untuk melindungi kulit dari radikal bebas adalah antioksidan dimana mampu menetralisir dampak radikal bebas dengan mengisi kekosongan elektron pada radikal bebas. Oleh karena itu, dibutuhkan antioksidan alami untuk digunakan secara topikal maupun oral dan harus dikembangkan ke dalam berbagai produk anti-aging. Penggunaan antioksidan alami dalam produk kosmetik memungkinkan menjaga kulit dan menambah antioksidan dengan cara yang sama seperti menjaga tubuh dengan mengkonsumsi buah dan sayuran ${ }^{3}$.

Salah satu tanaman Indonesia yang mengandung antioksidan yaitu berasal dari tanaman nilam (Pogostemon cablin Benth.). Minyak atsiri nilam mengandung patchouli alcohol. Uji aktivitas antioksidan dengan metode ABTS (2,2'-azino-bis(3ethylbenzothiazoline-6-sulphonic) menunjukkan minyak atsiri dari tanaman nilam berpotensi sebagai antioksidan dengan nilai IC50 sebesar $39.1 \mu \mathrm{g} / \mathrm{ml} \mathrm{l}^{4}$. Uji aktivitas antioksidan terhadap minyak atsiri nilam dengan metode DPPH (2,2'-diphenyl-1picrylhydrazyl) menunjukkan bahwa minyak atsiri nilam (Pogostemon cablin Benth.) ada aktivitas antioksidan dengan nilai IC50 sebesar $225,7 \mu \mathrm{g} / \mathrm{ml}$ dan hasil uji pendahuluan yang sudah dilakukan menunjukkan nilai IC50 dari minyak atsiri nilam (Pogostemon cablin Benth.) sebesar 533,163 $\mathrm{\mu g} / \mathrm{ml}$ yang termasuk kategori aktif sebagai aktivitas antioksidan ${ }^{5}$.

Penggunaan langsung minyak nilam sebagai antioksidan kurang stabil dengan adanya udara dan cahaya karena ada kemungkinan minyak nilam untuk menguap. Minyak nilam perlu diformulasikan dalam bentuk sediaan yang sesuai. Salah satu sistem penghantaran obat (Drug Delivery System) melalui kulit yang dikembangkan adalah dalam bentuk sediaan mikroemulsi. Sistem ini merupakan suatu emulsi dengan ukuran globul yang sangat kecil, yaitu sekitar 0,5-10 $\mu \mathrm{m}$ yang dengan ukuran tersebut globul dapat terpenetrasi baik hingga menembus epidermis ${ }^{6}$. Mikroemulsi merupakan suatu sistem dispersi yang dikembangkan dari sediaan emulsi. Mikroemulsi memiliki beberapa keuntungan yaitu stabil secara termodinamika, viskositas rendah, dan preparasi mudah ${ }^{7}$.

Penelitian Iskandar dkk sebelumnya telah memformulasi minyak nilam menjadi bentuk mikroemulsi $5 \%, 10 \%$ dan 15\% dengan hasil ukuran partikel $4,68 \mu \mathrm{m}, 1,48 \mu \mathrm{m}$ dan 1,32 $\mu \mathrm{m}^{8}$. Pada penelitian peneliti melanjutkan penelitian tersebut dengan melakukan pengujian dengan parameter yang akan dilihat adalah kelembaban, kehalusan, ukuran pori, noda dan keriput dengan menggunakan alat Skin analyzer (Aramo). Berdasarkan uraian diatas, maka penelitian ini perlu dilaksanakan untuk menguji aktivitas anti-aging yang diuji dengan menggunakan alat Skin analyzer (Aramo). 


\section{Metode}

Alat

Alat-alat yang digunakan dalam penelitian adalah timbangan analitik (Shimadzhu, Jepang), magnetic stirrer (Tianjin, China), termometer (Guandong, China), aluminium foil (Heilongjiang, China), hot plate (Thermo Scientific ${ }^{\mathrm{TM}}$ ), buret (Pyrex, USA), skin analyzer (Aramo, Korea), moisture checker (Aramo, Korea), dan alat-alat gelas (Pyrex, USA).

\section{Bahan}

Bahan yang digunakan dalam penelitian ini adalah Minyak atsiri nilam (Pogostemon cablin Benth.) (CV. Eteris Nusantara), polisorbat 80 cosmetic grade 99,9\% (Brataco), propilen glikol cosmetic grade 99,5\% (Brataco), sorbitol food grade $70 \%$ (Brataco), Virgin Coconut Oil (VCO) food grade 98\% (CV. Eteris Nusantara) dan aquadest murni (PT. Brataco Chemical, Indonesia).

\section{Prosedur Rinci}

1. Proses pembuatan mikroemulsi minyak dalam air $(\mathrm{m} / \mathrm{a})$ dilakukan dengan melarutkan minyak nilam dalam Virgin Coconut Oil (VCO) dan diaduk menggunakan magnetic stirrer pada suhu $50^{\circ} \mathrm{C}$ selama 10 menit dengan kecepatan $1000 \mathrm{rpm}$. Campuran tersebut ditambahkan polisorbat 80 dan sorbitol. Campuran yang telah homogen ditambahkan aquadest sedikit demi sedikit dan ditambahkan propilen glikol hingga campuran homogen ${ }^{9}$. Formulasi sediaan mikroemulsi dibuat dengan variasi konsentrasi blanko, minyak nilam 5\%,10\% dan 15\%. Formula sediaan mikroemulsi disajikan pada Tabel 1.

2. Pemeriksaan Organoleptik

Pemeriksaan organoleptis yaitu pengamatan secara visual terhadap bentuk, bau, warna, dan penampilan dari sediaan yang akan diamati setiap minggu selama 8 minggu $^{10}$.

3. Uji Iritasi Kulit

Pengujian dilakukan dengan uji tempel tertutup pada kulit manusia. Sediaan mikroemulsi diambil 0,1 gram, kemudian dioleskan pada lengan bagian dalam dengan ukuran $2 \times 2 \mathrm{~cm}$, ditutup dengan kain kasa dan diplester, dibiarkan 24 jam, diamati gejala yang timbul setelah 24 jam seperti kemerahan, gatal-gatal, dan reaksi sensitivitas lain yang mungkin timbul ${ }^{11}$.

4. Uji Aktivitas Anti-Aging Sediaan Mikroemulsi Minyak Nilam (Pogostemon cablin Benth.) Terhadap Punggung Tangan Sukarelawan

Pengujian aktivitas Anti-aging dilakukan dengan menggunakan 8 orang sukarelawan. Setiap sukarelawan diukur kondisi awal kulit pada bagian punggung tangan yang meliputi: kadar air (moisture), kehalusan (evenness), besar pori (pore), 
5. banyaknya noda (spot) dan keriput (wrinkle) dengan menggunakan skin analyzer. Setelah diukur kondisi awal kulit, mulai dilakukan pengolesan sediaan mikroemulsi hingga merata pada area kulit bagian punggung tangan ${ }^{12}$. Mikroemulsi tanpa minyak nilam/blanko (F0) dioleskan pada punggung tangan sukarelawan 1,2. Punggung tangan sukarelawan 3,4 dioleskan mikroemulsi minyak nilam formula I $(5 \%)$, punggung tangan sukarelawan 5,6 dioleskan mikroemulsi minyak nilam formula II (10\%), dan punggung tangan sukarelawan 7,8 dioleskan mikroemulsi minyak nilam formula III (15\%). Pengolesan dilakukan sebanyak 2 kali sehari pada saat pagi hari dan malam hari selama setiap hari sampai 30 hari. Perubahan kondisi kulit diukur pada hari ke-10, hari ke-20 dan hari ke-30 dengan menggunakan alat skin analyzer. Bandingkan kondisi kulit pada masing-masing sukarelawan.

6. Kadar Air (moisture)

Pengukuran kadar air dilakukan dengan alat moisture checker yang terdapat dalam perangkat skin analyzer Aramo. Caranya dengan menekan tombol power dan dilekatkan pada permukaan kulit. Angka yang ditampilkan pada alat merupakan persentase kadar air dalam kulit yang diukur ${ }^{13}$.

7. Kehalusan (evenness)

Pengukuran kehalusan kulit dilakukan dengan perangkat skin analyzer pada lensa perbesaran 60x dan menggunakan lampu sensor biru (normal). Kamera diletakkan pada permukaan kulit yang akan diukur kemudian tekan tombol capture untuk memfoto dan secara otomatis hasil berupa angka dan kondisi kulit yang didapatkan akan tampil pada layar komputer ${ }^{13}$.

8. Pori (pore)

Pengukuran besarnya pori pada kulit secara otomatis akan keluar pada saat melakukan pengukuran pada kehalusan kulit. Gambar yang telah terfoto pada pengukuran kehalusan kulit juga akan keluar pada kotak bagian pori-pori kulit. Hasil berupa angka dan penentuan ukuran pori secara otomatis akan keluar pada layar komputer ${ }^{13}$.

9. Noda (spot)

Pengukuran banyaknya noda yang dilakukan dengan perangkat Skin analyzer pada lensa perbesaran 60x dan menggunakan lampu sensor jingga (terpolarisasi). Kamera diletakkan pada permukaan kulit yang akan diukur kemudian tekan tombol capture untuk memfoto dan secara otomatis hasil berupa angka dan penentuan banyaknya noda yang didapatkan akan tampil pada layar komputer ${ }^{13}$.

10. Keriput (wrinkle)

Pengukuran keriput dilakukan dengan perangkat skin analyzer pada lensa perbesaran 10x dan menggunakan lampu sensor biru (normal). Kamera diletakkan pada permukaan kulit yang akan diukur kemudian tekan tombol capture untuk memfoto dan secara otomatis hasil berupa angka dan kondisi kulit yang didapatkan akan tampil pada layar komputer. 
Pada pengukuran ini, tidak hanya jumlah keriput yang dapat diukur, akan tetapi kedalaman keriput juga dapat terdeteksi dengan alat skin analyzer ${ }^{13}$.

\section{Hasil}

Pemeriksaan Organoleptik Sediaan Mikroemulsi

Pemeriksaan organoleptis sediaan mikroemulsi minyak nilam meliputi bentuk, warna, bau dan kejernihan. Sediaan mikroemulsi minyak nilam F1, F2 dan F3 yang diperoleh berbentuk cairan, warna kuning muda, berbau khas minyak nilam, dan jernih. Pada F0 diperoleh berbentuk cairan, warna putih, bau khas VCO, dan agak jernih. Pemeriksaan organoleptis yang dilakukan pada keempat formula sediaan mikroemulsi meliputi bentuk, warna, bau, dan kejernihan ${ }^{14}$.

\section{Uji Iritasi Kulit}

Hasil uji iritasi menunjukkan bahwa tidak ada terjadi iritasi pada 12 panelis. Hasil pengujian ditandai dengan tidak memperlihatkan adanya reaksi iritasi seperti kulit memerah, gatal-gatal, atau reaksi iritasi lainnya. Sehingga sediaan ini aman untuk digunakan ${ }^{15}$.

\section{Uji Aktivitas Anti-aging Sediaan Mikroemulsi}

Uji aktivitas anti-aging sediaan mikroemulsi minyak nilam menunjukkan bahwa semua formula mengalami pemulihan terhadap kadar air (moisture), kehalusan kulit (evenness), besar pori (pore), noda (spot) dan keriput (wrinkle) ${ }^{16}$. Dari hasil yang didapatkan berdasarkan persentase pemulihan didapatkan bahwa formula mikroemulsi minyak nilam $\mathrm{F} 1(5 \%)$ lebih cepat terjadi pemulihan dibandingkan sediaan mikroemulsi formula F3 (15\%), F2 (10\%) dan F0 (0\%).

\section{Kadar Air (Moisture)}

Kadar air diukur pada bagian punggung tangan sukarelawan dan diukur menggunakan alat moisture checker yang terdapat dalam perangkat skin analyzer Aramo. Pada alat uji Aramo, kulit terdehidrasi ditandai dengan kadar air 0-29, kulit normal memiliki kadar air 30-44, dan kulit hidrasi mempunyai kadar air 45-100 13,16 . Data hasil pengukuran kadar air (moisture) pada punggung tangan sukarelawan menunjukkan bahwa kadar air pada punggung tangan semua kelompok sukarelawan sebelum pemakaian sediaan mikroemulsi adalah dalam keadaan dehidrasi dan selama penggunaan sediaan mikroemulsi menunjukkan peningkatan pada kadar air kulit. Hasil persentese rata-rata pemulihan kadar air dapat dilihat pada Tabel 2.

\section{Kehalusan (Evenness)}

Pengukuran kehalusan kulit (evenness) dilakukan dengan menggunakan perangkat skin analyzer Aramo lensa perbesaran 60x dengan sensor biru. Pada alat uji Aramo, kulit halus ditandai dengan kadar kehalusan 0-31, kulit normal memiliki kehalusan 32-51 dan kulit kasar berada pada kisaran 52-10013,16. Data hasil pengukuran kehalusan kulit (evenness) pada punggung tangan sukarelawan menunjukkan bahwa kehalusan pada punggung tangan semua kelompok sukarelawan sebelum pemakaian sediaan mikroemulsi adalah normal. Hasil persentese pemulihan kehalusan kulit dapat dilihat pada Tabel 3. 


\section{Pori (Pore)}

Pengukuran besar pori menggunakan perangkat skin analyzer yaitu dengan lensa perbesaran 60 kali dengan warna lampu sensor berwarna biru, pada saat melakukan pengukuran kehalusan kulit, maka secara otomatis pengukuran pori juga terukur. Pada alat uji Aramo, pori kecil ditandai dengan angka 0-19, pori sedang berada pada kisaran 20-39, dan pori sangat besar pada angka 40-10013,16. Data hasil pengukuran pori (pore) pada punggung tangan sukarelawan menunjukkan bahwa besar pori pada punggung tangan semua kelompok sukarelawan sebelum pemakaian sediaan mikroemulsi adalah pori dalam ukuran yang besar. Setelah pemakaian selama 30 hari besar pori kulit sukarelawan menjadi kategori sedang. Hasil persentase rata-rata pemulihan pengukuran pori dapat dilihat pada Tabel 4.

\section{Noda (Spot)}

Pengukuran banyaknya noda (spot) dilakukan dengan menggunakan perangkat skin analyzer lensa perbesaran 60x sensor berwarna jingga. Pada alat uji Aramo, jumlah noda sedikitditandai dengan angka $0-19$, noda sedang berada pada kisaran $20-39$, dan noda sangat banyak jika angka $40-100^{13,16}$. Data hasil pengukuran banyaknya noda (spot) pada punggung tangan sukarelawan menunjukkan bahwa banyaknya noda pada punggung tangan semua kelompok sukarelawan sebelum pemakaian sediaan mikroemulsi adalah mempunyai noda yang sedang hingga kategori banyak. Setelah pemakaian selama 30 hari banyaknya noda pada punggung tangan sukarelawan mengalami pengurangan. Hasil pemulihan banyaknya noda dapat dilihat pada Tabel 5 .

\section{Keriput (Wrinkle)}

Pengukuran keriput dengan menggunakan perangkat alat skin analyzer menggunakan lensa perbesaran 10 kali dengan lampu sensor berwarna biru ${ }^{16}$. Data hasil pengukuran keriput (wrinkle) pada punggung tangan sukarelawan menunjukkan tingkat keriput pada punggung tangan semua kelompok sukarelawan sebelum pemakaian sediaan mikroemulsi adalah berkeriput. Setelah pemakaian selama 30 hari tingkat keriput pada punggung tangan sukarelawan mengalami pengurangan hingga menjadi tidak berkeriput. Persentase pemulihan keriput dapat dilihat pada Tabel 6 .

\section{Pembahasan}

Dari pengamatan yang dilakukan didapatkan bahwa sediaan mikroemulsi F1, F2, dan F3 memiliki bentuk yang cair, warna kuning muda, bau khas minyak nilam, dan sediaan yang jernih. Pada formula F0 yaitu tanpa minyak nilam didapatkan bentuk yang cair, warna putih, tidak berbau, dan agak jernih. Penampilan yang agak jernih pada VCO terjadi karena VCO merupakan trigliserida, trigliserida bersifat berpermukaan aktif sehingga tidak mampu membentuk lapisan minyak pada sistem ampifilik-air yang mengakibatkan sediaan tidak menjadi jernih ${ }^{17}$. Tidak terjadinya perubahan pada masing-masing formula sediaan mikroemulsi setelah 8 minggu penyimpanan menandakan bahwa sediaan mikroemulsi minyak atsiri nilam stabil secara organoleptis $^{18}$. 
Berdasarkan dari hasil uji iritasi yang dilakukan pada 12 sukarelawan yaitu dengan uji tempel tertutup pada pada lengan bagian dalam sebanyak 0,1 gram dengan ukuran $2 \mathrm{x}$ $2 \mathrm{~cm}^{19}$. Setelah ditutup dengan kain kasa dan diplester selama 24 jam, mikroemulsi tidak menunjukkan adanya parameter reaksi iritasi. Parameter yang diamati yaitu adanya kulit merah, dan pembengkakan setelah sediaan diaplikasikan. Dari hasil uji iritasi yang dilakukan, disimpulkan bahwa sediaan yang dibuat aman untuk digunakan ${ }^{20}$.

Berdasarkan hasil analisa statistik menggunakan ANOVA dua arah terdapat perbedaan peningkatan kadar air yang signifikan $(p<0,05)$ dari pemakaian awal hingga hari ke-30. Setelah pemakaian 30 hari terdapat perbedaan yang signifikan $(p<0,05)$ antara F0 dengan F1, F2, dan F3. Selanjutnya antara F1 dengan F0, F2 dan F3 terdapat perbedaan yang signifikan ( $p<0,05$ ), antara F2 dengan F0 dan F1 terdapat perbedaan yang signifikan $(p<0,05)$ sedangkan dengan F3 tidak terdapat perbedaan yang signifikan $(p>0,05)$. F3 dan F2 tidak terdapat perbedaan yang signifikan $(p>0,05)$. Artinya, konsentrasi mikroemulsi F1 (5\%) menunjukkan hasil yang lebih baik dibandingkan dengan $\mathrm{F} 0(0 \%), \mathrm{F} 2(10 \%)$, dan F3(15\%) terhadap pemulihan persentase kadar air. Kadar air merupakan parameter yang penting dalam menjaga kelenturan kulit, semakin berkurang kadar air, maka kulit akan semakin kaku dan mudah mengalami penuaan $^{21}$.

Hasil data statistik dalam pengecilan ukuran pori menunjukkan adanya perbedaan yang signifikan $(p<0,05)$ terhadap dua variabel yaitu konsentrasi dan waktu. Hasil uji Tukey pada variabel konsentrasi menunjukkan bahwa pada formula tanpa minyak nilam (F0) tidak terdapat perbedaan yang signifikan $(p>0,05)$ terhadap F2 dan F3, tetapi berbeda signifikan $(p<0,05)$ terhadap F1. F1 tidak terdapat perbedaan yang signifikan terhadap $F 2$, dan F3, tetapi terdapat perbedaan yang signifikan $(p<0,05)$ terhadap F0. F2 dan F3 tidak terdapat perbedaan yang signifikan $(p>0,05)$ terhadap semua formula. Hasil uji Tukey pada variabel waktu hari ke 0 berbeda signifikan $(p<0,05)$ terhadap hari ke-7, hari ke-15 dan hari ke-30. Hari ke-7 tidak terdapat perbedaan yang signifikan $(p>0,05)$ terhadap hari ke-15. Pada hari ke-30 terdapat perbedaan yang signifikan $(p<0,05)$ terhadap hari ke-0, ke-7 dan ke-15. Artinya, pada variabel konsentrasi mikroemulsi F1 (5\%) menunjukkan hasil yang lebih baik dibandingkan dengan F0 (0\%) terhadap pemulihan besar pori. Ukuran pori-pori berhubungan erat dengan kehalusan pada kulit. Semakin kecil ukuran pori-pori pada kulit menunjukkan semakin halus kulit tersebut, sebaliknya semakin besar ukuran pori-pori menunjukkan semakin kasar kulit tersebut ${ }^{22}$.

Pengukuran banyaknya noda dianalisa dengan Anova dan menunjukkan adanya perbedaan yang signifikan $(p<0,05)$ dari persentase pengurangan noda terhadap dua variabel yaitu konsentrasi dan waktu. Hasil uji Tukey pada variabel konsentrasi menunjukkan bahwa pada formula tanpa minyak nilam (F0) terdapat perbedaan yang signifikan $(p<0,05)$ terhadap $F 1, F 2$ dan F3. F1 tidak terdapat perbedaan yang signifikan terhadap F2 dan F3, tetapi terdapat perbedaan yang signifikan $(p<0,05)$ terhadap F0. F2 dan F3 terdapat perbedaan yang signifikan $(p<0,05)$ terhadap F0, tetapi tidak terdapat perbedaan yang signifikan terhadap F1. Hasil uji Tukey pada variabel waktu hari ke 0 tidak terdapat perbedaan yang signifikan $(p>0,05)$ terhadap hari ke-7, tetapi terdapat perbedaan yang signifikan $(p<0,05)$ terhadap hari ke-15 dan hari ke-30, 
. Hari ke-15 dan hari ke-30 terdapat perbedaan yang signifikan $(p<0,05)$ terhadap hari ke-0 dan ke-7. Artinya, pada variabel konsentrasi mikroemulsi F1 (5\%) menunjukkan hasil yang lebih baik dibandingkan dengan $\mathrm{F} 0(0 \%)$ terhadap pemulihan banyak noda.

Pengujian dengan Anova untuk parameter keriput tidak menunjukkan adanya perbedaan yang signifikan $(p>0,05)$ dari persentase pemulihan keriput terhadap konsentrasi, akan tetapi terdapat perbedaan yang signifikan $(p<0,05)$ terhadap variabel waktu. Hasil uji Tukey pada variabel waktu tidak terdapat perbedaan yang signifikan $(p>0,05)$ antara hari ke-0 dengan hari ke-7, tetapi terdapat perbedaan yang signifikan $(p<0,05)$ terhadap hari ke-15 dan hari ke-30. Hari ke-15 terdapat perbedaan yang signifikan $(p<0,05)$ terhadap hari ke-0 dan ke-7, tetapi tidak terdapat perbedaan yang signifikan $(p>0,05)$ terhadap hari ke 30 . Artinya, pada variabel konsentrasi tidak terdapat perbedaan yang signifikan $(p>0,05)$ pada pemulihan keriput. Akan tetapi, pada variabel waktu hari ke-30 semua formula mengalami pemulihan tingkat keriput.

Dari keseluruhan hasil tersebut dapat disimpulkan bahwa konsentrasi yang memiliki efektivitas yang baik yaitu sediaan mikroemulsi minyak nilam konsentrasi $5 \%$ dan pada konsentrasi tersebut memiliki ukuran partikel paling kecil. Ukuran partikel juga secara signifikan mempengaruhi efektivitas formula, bahwa semakin kecil ukuran partikel semakin mudah sediaan untuk menembus permukaan kulit, sehingga dapat meningkatkan penetrasi ke dalam kulit dan dapat menghasilkan efektivitas yang sangat baik sebagai anti penuaan ${ }^{13,16}$.

\section{Kesimpulan}

Berdasarkan hasil penelitian yang dilakukan dapat disimpulkan bahwa formula yang memiliki aktivitas anti-aging yang lebih baik pada kulit adalah $\mathrm{F} 1$ dengan konsentrasi minyak nilam 5\% dibandingkan dengan F3 (15\%), F2 (10\%) dan F0 (0\%), yaitu ditandai dengan adanya perubahan kondisi kulit pada tiap-tiap parameter aging kulit seperti kadar air (moisture), kehalusan (evenness), pori (pore), noda (spot) dan kerutan (wrinkle) berdasarkan persentase pemulihan.

\section{Ucapan terima kasih}

Ucapan terima kasih disampaikan kepada pihak Pimpinan dan Laboran Sekolah tinggi ilmu farmasi Riau (STIFAR) yang telah banyak membantu dalam proses penyelesaian penelitian ini. Serta semua pihak dan tim yang terlibat sehingga penelitian ini dapat terselesaikan dengan baik.

\section{Daftar Pustaka}

1. Masnec IS, Poduje S. Photoaging. Coll. Antropol. 2008;32(2):177-180.

2. Dewi RK. Optimasi Formulasi Mikroemulsi Sediaan Hormon Testosteron Undekanoat. Jakarta: Universitas Islam Negeri Syarif Hidayatullah; 2010. 
3. Herawati Y. Pemberian Oral Ekstrak Daun Pegagan (Centella asiatica) Lebih Banyak Meningkatkan Jumlah Kolagen dan Menurunkan Ekspresi MMP-1 daripada Vitamin C Pada Tikus Wistar (Rattus norvegicus) yang dipapar sinar UVB. [Tesis]. Denpasar: Program Magister Program Studi IImu Biomedik Universitas Udayana Denpasar; 2014.

4. Pouillot A, Polla LL, Tacchini P, Neequaye A, Polla A, Polla B. Natural Antioxidants and their Effects on the Skin. Formulating, Packaging, and Marketing of Natural Cosmetic Products. Switzerland: John Wiley \& Sons, Inc. 2011.

5. Pathan M, Zikriya A, Quazi A. Microemulsion: As Excellent Drug Delivery System. International Journal for Pharmaceutical Research Scholars (IJPRS). 2012;1(3): 199-210.

6. Pradeep DP, Murugan K. Comparative Study on Antioxidant Activity Of Essential Oils From Pogostemon benghalensis (Burm.F.) Kuntze. And P. cablin (Blanco) Benth. World Journal Of Pharmaceutical Research. 2019;8(2): 1301-1313.

7. Mustika. Pengaruh Metode Distilasi dan Komposisi Bahan Baku Terhadap Jumlah Rendemen Serta Mutu Minyak Nilam. Tesis. Surabaya: Institut Teknologi Surabaya; 2008.

8. Iskandar B, Lukman A, Tartilla R, Dwi Condro Surboyo M, Leny. Formulasi, Karakterisasi, dan Uji Stabilitas Mikroemulsi Minyak Nilam (Pogostemon cablin Benth.). Jurnal Ilmiah Ibnu Sina. 2021;6(2):282-291. https://doi.org/10.36387/jiis.v6i2.724

9. Yuwanti, S., Raharjo, S., Hastuti, P, dan Supriyadi, S. Formulasi Mikroemulsi Minyak dalam Air (O/W) yang Stabil Menggunakan Kombinasi Tiga Surfaktan Non lonik dengan Nilai Hlb Rendah, Tinggi dan Sedang. Agritech. 2011;31(1): 21-29.

10. Iskandar B, Sidabutar SE, Leny. Formulasi dan Evaluasi Lotion Ekstrak Alpukat (Persea americana) sebagai Pelembab Kulit. Jurnal Islamic Pharmacy. 2021;6(1): 14-21.

11. Tirmiara N, Reveny J, Silalahi J. Formulation and Evaluation of Moringa Seed Oil Nanoemulsion Gel. Asian Journal of Pharmaceutical Research and Development. 2019;7(6): 1-5.

12. Paul BK, Moulik SP. Uses and application of microemulsions. Current Science. 2001;80(8): 990-1001.

13. Iskandar B, Karsono, Silalahi J. Preparation of Spray Nanoemulsion and Cream Containing Vitamin E as Anti-aging Product Tested in Vitro and in Vivo Method. International Journal PharmaTech Research. 2016;9(6): 307-308.

14. Ariviani S, Raharjo $S$, Anggrahini $S$, Naruki S. Formulasi Dan Stabilitas Mikroemulsi O/W Dengan Metode Emulsifikasi Spontan Menggunakan Vco Dan Minyak Sawit Sebagai Fase Minyak: Pengaruh Rasio Surfaktan-Minyak. Jurnal Agritech. 2015;35(1): 27-33. 
15. Iskandar B, Ernilawati M, Agustini TT, Firmansyah F, Frimayanti N. Formulasi blush on stick dengan zat pewarna alami ekstrak kering buah naga merah (Hylocereus polyrhizus L.). Cendekia journal of pharmacy. 2021;5(1): 70-80.

16. Leny, Karsono, Harahap U. Comparison of Vitamin C (Magnesium Ascorbyl Phosphate) Formulation in Nanoemulsion Spray and Cream as Anti-aging. International Journal of PharmTech Research. 2016;9(9): 399-407.

17. Kishore RSK, Astrid P, Kiese S, Fischer S, Isabelle BD, Alfred R, et al. The Degradation of Polysorbates 20 And 80 And Its Potential Impact on the Stability of Biotherapeutics. Pharmaceautical Research. 2011;28(5): 1194-1210.

18. Leny et al. Formulasi dan Uji Efektivitas Sediaan Body scrub Labu Kuning (Curcubita moschata). Majalah Farmasetika, 2021;6(4): 375-385 doi: https://doi.org/10.24198/mfarmasetika.v6i4.35776

19. Septianingrum SN. Optimasi Formula Mikroemulsi Testosteron Undekanoat (TU) dengan Kekuatan Sediaan yang Optimum pada Penggunaan Injeksi Intremuskular. (Skripsi). Jakarta: Fakultas Kedokteran dan IImu Kesehatan Universitas Islam Negeri Syarif Hidayatullah; 2013.

20. Mandal A, Bera A. Surfactant Stabilized Nanoemulsion: Characterization and Application in Enhanced Oil Recovery. International Scholarly and Scientific Research \& Innovation. 2012;6(7): 537-542.

21. Leny, Fitri K, Marantina R, Ginting PA, Syamsul D, Hafiz I. The Moisturizing Sheet Mask Formulation of Black Soybean (Glycine soja) Ethanolic Extract. International Journal of Advanced Science and Technology. 2020;29(4): 90459051.

22. Ginting M, Fitri K, Leny, Lubis BK. Formulasi dan Uji Efektivitas Anti-aging dari masker clay ekstrak etanol kentang kuning (Solanum tuberosum L.). Jurnal Dunia Farmasi. 2020;4(2): 68-75.

Tabel 1 Formulasi Sediaan Mikroemulsi

\begin{tabular}{|c|c|c|c|c|c|}
\hline \multirow{2}{*}{ Bahan } & \multicolumn{4}{|c|}{ Formula (\%) } & \multirow[t]{2}{*}{ Fungsi } \\
\hline & $\mathbf{0}$ & I & II & III & \\
\hline Minyak Nilam & 0 & 5 & 10 & 15 & Zat aktif \\
\hline $\mathrm{VCO}$ & 3 & 3 & 3 & 3 & Fase minyak \\
\hline Polisorbat 80 & 25 & 25 & 25 & 25 & Surfaktan \\
\hline Sorbitol & 10 & 10 & 10 & 10 & Kosurfaktan \\
\hline Propilen Glikol & 15 & 15 & 15 & 15 & Pengawet dan humektan \\
\hline Aquadest ad & 100 & 100 & 100 & 100 & Fase air \\
\hline
\end{tabular}

Tabel 2 Persentase Rata-rata Peningkatan Kadar Air (Moisture) Selama 30 Hari 
Tabel 2 Persentase Rata-rata Peningkatan Kadar Air (Moisture) Selama 30 Hari

\begin{tabular}{cccccc}
\hline & & \multicolumn{4}{c}{ Persen peningkatan Kadar Air } \\
\cline { 3 - 5 } Formula & Sukarelawan & & \multicolumn{2}{c}{ Pemakaian Hari ke- } \\
\cline { 3 - 5 } & & $\mathbf{0}$ & $\mathbf{1 0}$ & $\mathbf{2 0}$ & $\mathbf{3 0}$ \\
\hline \multirow{3}{*}{ F0 } & 1 & 0 & 0 & 2 & 4 \\
& 2 & 0 & 0 & 1 & 3 \\
& Rata-Rata & 0 & 0 & 1,5 & 3,5 \\
F1 & 1 & 0 & 3 & 7 & 11 \\
& 2 & 0 & 5 & 9 & 13 \\
& Rata-Rata & 0 & 4 & 8 & 12 \\
F2 & 1 & 0 & 2 & 6 & 7 \\
& 2 & 0 & 1 & 3 & 7 \\
& Rata-Rata & 0 & 1,5 & 4,5 & 7 \\
F3 & 1 & 0 & 2 & 5 & 7 \\
& 2 & 0 & 3 & 4 & 7 \\
\hline
\end{tabular}

Keterangan:

F0 : sediaan mikroemulsi blanko (tanpa minyak nilam)

F1 : sediaan mikroemulsi minyak nilam $5 \%$

F2 : sediaan mikroemulsi minyak nilam $10 \%$

F3 : sediaan mikroemulsi minyak nilam $15 \%$

Tabel 3 Persentase rata-rata Pemulihan Tingkat Kehalusan (Evenness) Selama 30 Hari

Persen pemulihan Kehalusan

\begin{tabular}{cccccc}
\cline { 3 - 5 } Formula & Sukarelawan & \multicolumn{4}{c}{ Pemakaian hari ke- } \\
\cline { 3 - 5 } & & $\mathbf{0}$ & $\mathbf{1 0}$ & $\mathbf{2 0}$ & $\mathbf{3 0}$ \\
\cline { 3 - 6 } F0 & 1 & 0 & 0 & 11,76 & 23,53 \\
& 2 & 0 & 0 & 15,15 & 21,21 \\
& Rata-Rata & 0 & 0 & 13,43 & 22,39 \\
F1 & 1 & 0 & 10,53 & 23,68 & 26,32 \\
& 2 & 0 & 6,45 & 16,14 & 25,81 \\
& Rata-Rata & 0 & 8,70 & 20,29 & 26,09 \\
F2 & 1 & 0 & 6,25 & 9,38 & 21,88 \\
& 2 & 0 & 2,63 & 21,05 & 26,32 \\
& Rata-Rata & 0 & 4,29 & 15,71 & 24,29 \\
F3 & 1 & 0 & 5,41 & 10,81 & 24,32 \\
& 2 & 0 & 5 & 15 & 27,50 \\
& Rata-Rata & 0 & 5,19 & 12,99 & 25,97 \\
\hline
\end{tabular}




\section{Keterangan:}

F0 : sediaan mikroemulsi blanko (tanpa minyak nilam)

F1 : sediaan mikroemulsi minyak nilam $5 \%$

F2 : sediaan mikroemulsi minyak nilam $10 \%$

F3 : sediaan mikroemulsi minyak nilam $15 \%$

Tabel 4 Persentase Rata-rata Pemulihan Ukuran Pori (Pore) Selama 30 Hari

\section{Persen pemulihan ukuran pori}

\begin{tabular}{cccccc}
\cline { 3 - 5 } Formula & Sukarelawan & \multicolumn{4}{c}{ Pemakaian hari ke- } \\
\cline { 3 - 5 } & & $\mathbf{0}$ & $\mathbf{1 0}$ & $\mathbf{2 0}$ & $\mathbf{3 0}$ \\
\hline \multirow{3}{*}{ F0 } & 1 & 0 & 0 & 27,12 & 44,07 \\
& 2 & 0 & 0 & 5,77 & 30,77 \\
& Rata-Rata & 0 & 0 & 17,12 & 37,84 \\
F1 & 1 & 0 & 34,55 & 41,82 & 52,73 \\
& 2 & 0 & 29,79 & 29,79 & 48,94 \\
& Rata-Rata & 0 & 32,35 & 36,27 & 50,98 \\
F2 & 1 & 0 & 18,87 & 28,30 & 33,96 \\
& 2 & 0 & 13,04 & 24,64 & 46,38 \\
& Rata-Rata & 0 & 15,57 & 26,23 & 40,98 \\
F3 & 1 & 0 & 14,29 & 20,41 & 32,65 \\
& 2 & 0 & 21,43 & 35,71 & 59,52 \\
& Rata-Rata & 0 & 17,58 & 27,47 & 45,05 \\
\hline
\end{tabular}

\section{Keterangan:}

F0 : sediaan mikroemulsi blanko (tanpa minyak nilam)

F1 : sediaan mikroemulsi minyak nilam $5 \%$

F2 : sediaan mikroemulsi minyak nilam $10 \%$

F3 : sediaan mikroemulsi minyak nilam $15 \%$ 
Tabel 5 Persentase Rata-rata Pemulihan Banyaknya Noda (Spot) Selama 30 Hari

\begin{tabular}{cccccc}
\hline \multirow{2}{*}{ Formula } & \multirow{3}{*}{ Sukarelawan } & \multicolumn{4}{c}{ Persen pengurangan noda } \\
\cline { 3 - 5 } & & \multicolumn{4}{c}{ Pemakaian hari ke- } \\
\cline { 3 - 5 } F0 & 1 & 0 & 0 & $\mathbf{1 0}$ & $\mathbf{3 0}$ \\
& 2 & 0 & 0 & 8,96 & 11,76 \\
& Rata-Rata & 0 & 0 & 4,57 & 20 \\
F1 & 1 & 0 & 12,50 & 25 & 15,12 \\
& 2 & 0 & 23,08 & 43,08 & 62,50 \\
& Rata-Rata & 0 & 19,59 & 37,11 & 63,92 \\
F2 & 1 & 0 & 5,36 & 14,29 & 42,86 \\
& 2 & 0 & 11,11 & 33,33 & 53,33 \\
& Rata-Rata & 0 & 7,92 & 22,77 & 47,52 \\
F3 & 1 & 0 & 8,70 & 17,39 & 47,83 \\
& 2 & 0 & 10,71 & 30,36 & 64,29 \\
& Rata-Rata & 0 & 10,13 & 26,58 & 59,49 \\
\hline
\end{tabular}

\section{Keterangan:}

F0 : sediaan mikroemulsi blanko (tanpa minyak nilam)

F1 : sediaan mikroemulsi minyak nilam 5\%

F2 : sediaan mikroemulsi minyak nilam $10 \%$

F3 : sediaan mikroemulsi minyak nilam 15\%

Tabel 6 Persentase Rata-rata Pemulihan Banyaknya Keriput (Wrinkle) Selama 30 Hari

\begin{tabular}{cccccc}
\hline \multirow{2}{*}{ Formula } & Sukarelawan & \multicolumn{4}{c}{ Keriput (Wrinkle) } \\
\cline { 3 - 5 } & & \multicolumn{4}{c}{ Pemakaian hari ke- } \\
\cline { 3 - 5 } & 1 & $\mathbf{0}$ & $\mathbf{1 0}$ & $\mathbf{2 0}$ & $\mathbf{3 0}$ \\
\hline \multirow{2}{*}{ F0 } & 2 & 0 & 0 & 31,58 & 36,84 \\
& Rata-Rata & 0 & 0 & 33,33 & 40,74 \\
& 1 & 0 & 41,03 & 48,72 & 66,67 \\
F1 & 2 & 0 & 17,02 & 42,55 & 65,96 \\
& Rata-Rata & 0 & 27,91 & 45,35 & 66,28 \\
& 1 & 0 & 42,31 & 57,69 & 69,23 \\
F2 & 2 & 0 & 0 & 33,33 & 50 \\
& Rata-Rata & 0 & 28,95 & 50 & 63,16 \\
& 1 & 0 & 0 & 20 & 50 \\
F3 & 2 & 0 & 28,57 & 50 & 64,29 \\
& Rata-Rata & 0 & 16,67 & 37,5 & 58,33 \\
\hline
\end{tabular}

\section{Keterangan:}

F0 : sediaan mikroemulsi blanko (tanpa minyak nilam)

F1 : sediaan mikroemulsi minyak nilam 5\%

F2 : sediaan mikroemulsi minyak nilam $10 \%$

F3 : sediaan mikroemulsi minyak nilam $15 \%$ 